\title{
Financial catastrophism inherent with out-of-pocket payments in long term care for households: a latent impoverishment
}

\author{
Raul del Pozo-Rubio \\ Universidad de Castilla-La Mancha \\ Isabel Pardo ( $\sim$ isabel.pardo@uclm.es) \\ Universidad de Castilla-La Mancha https://orcid.org/0000-0003-4391-6011 \\ Francisco Escribano-Sotos \\ Universidad de Castilla-La Mancha
}

\section{Research article}

Keywords: out of pocket payments, catastrophic long-term care payments, impoverishing, poverty impact

Posted Date: August 15th, 2019

DOI: https://doi.org/10.21203/rs.2.13033/v1

License: (c) (i) This work is licensed under a Creative Commons Attribution 4.0 International License.

Read Full License

Version of Record: A version of this preprint was published at International Journal of Environmental Research and Public Health on January 1st, 2020. See the published version at https://doi.org/10.3390/ijerph17010295. 


\section{Abstract}

Background Out-of-pocket (OOP) payments are configured as an important source of financing long-term care (LTC). However, very few studies have analyzed the risk of impoverishment and catastrophic effects of OOP in LTC. Objective To estimate the contribution of users to the financing of LTC and to analyze the economic consequences for households in terms of impoverishment and catastrophism. Data and Methods The data base which was used is 2008 Spanish Disability and Dependency Survey, projected to 2012. We analyze the OOP payments effect associated to the impoverishment of households comparing volume and financial situation before and after OOP payment. At the same time, the extent to which OOP payment had led to catastrophism was analyzed using different thresholds. Results The results show that contribution of dependent people to the financing of the services they receive exceeds by $50 \%$ the costs of these services. This expenditure entails an increase in the number of households that live below the poverty. In terms of catastrophism, more than $80 \%$ of households dedicate more than $10 \%$ of their income to dependency OOP payments. In annual terms, the catastrophe gap generated by devoting more than $10 \%$ of the household income to dependent care OOP payment reached $€ 3,955,1$ million $(0,38 \%$ of GDP). Conclusion This article informs about consequences of OOP in LCT and supplements previous research that focus on health. Our results should serve to develop strategic for protection against the financial risk resulting from facing the costs of a situation of dependence.

\section{Background}

Total spending on health care on average accounts for $9 \%$ of GDP in the OECD while long-term care (LTC) absorbs $1.5 \%$ of GDP $[1,2]$. Given the rates of world population ageing and dependence, this spending will continue to rise in the coming years [2] and put upward pressure on public finances, although some studies reveal the opposite [3]. In a context of fiscal restraint and reduction of public debt, governments implement measures aimed at containing health and long-term care expenditure. Some of these measures are out-of-pocket (OOP) payments and insurance in LTC field.

OOP payments associated with LTC are defined as beneficiary participation in the cost of a service. It has two functions: to gain efficiency from the use of an asset and/or service, curtailing excessive demand, known as moral hazard, which arises when the price paid by a consumer is lower than the marginal value or utility [4-6], and reducing costs by raising additional financial resources.

According to Xu et al. (2007) [7] many countries rely heavily on patients' OOP payments to providers to finance their health care systems but there is widespread debate in public health systems on whether to establish a OOP payment or not, and the effects that OOP payment has on the use of services, trying to determine if there is a negative price elasticity between price and service use. There is an extensive literature examining the impact of out-of-pocket expenditures for drugs and health services [8-11]. In their systematic review, Kiil and Houlrberg (2014) [12] find that OOP payment has a negative effect on demand, except in the case of hospitalizations, and reduces the use of prescription medicine. Others 
studies suggest that OOP payment increases were also found to lead to decreased utilization of services, including hospitalizations, physician visits, prescription drugs, and outpatient clinic visits [13].

OOP payments also impact on equity $[14,15]$ join to catastrophe and impoverishment although the literature has devoted less attention to these issues. According to Antonanzas and Brías (2013) [16], few studies have been conducted on the effects of OOP on equity and no conclusions have been reached, although, for example, reduced use of prescription drugs in response to higher OOP payments by lowincome adults on public assistance have also been reported in Canada [17]. Kiil and Houlberg (2014) [12] indicate that some studies find an association between low income and higher elasticity-price of demand, while others do not. In the same vein, González López-Valcárcel et al., (2016) [5] only locate three studies analyzing the effect of OOP payment on the use of health services by vulnerable population groups.

Although the literature on catastrophe and impoverishment is also limited [18-23], the results show that the implementation of health care OOP payment puts many households at financial risk. Even a small payment can generate a financial problem in a poor household, forcing the reduction of other basic expenses such as food, hygiene, or the education of their children, which affects quality of life while families may fall into poverty or become poorer.

A review of the literature on OOP payment shows that its effects on health, although varying, are well documented. In the case of private health insurance systems, a number of studies in the United States analyze the effect of the lack of health insurance on the chronically ill [24-28] or people with disabilities [29-33]. However, those analyzing the effects of OPP payments or health insurance on LTC are more limited in number although interest in this issue is growing. Some studies have analyzed OOP payments for specific components of health care such as the chronically ill $[34,35]$ and the disabled population [36-38]. In addition, a study across the OECD has measured the protection of long-term care and differences between countries. For example, in the United States, people with assets are expected to use them to pay for care until they become legally impoverished and eligible for social protection [39].

In Spain, LTC system is funded by revenue from taxes and user's OOP payments. Specifically, the 2006 Act for the Promotion of Personal Autonomy and Care of Dependent Persons [40], commonly known as Dependency Act (DA), sets out that users will contribute a third of the cost of the service, depending on their economic situation. The limited number of studies conducted in this regard $[41,42]$ show that their contribution is far from this quantity, being between 28.5 and $21.3 \%$. In 2012, against a backdrop of economic crisis and faced by the need to reduce public debt, the government amended the legislation on OOP payment, leading to user contributions to rise to $50 \%[43,44]$. Table 1 shows the differences in the legislation before and after 2012 for OOP payments associated with LTC. This legislative reform has had no effect on the demand for services because despite not being wholly insensitive to OPP payments, it is generally accepted that demand for LTC services is inelastic, and can this have an impact on equity. Furthermore, the amendment implemented in 2012, in a situation of economic crisis, makes it more relevant to analyze the effect it has had in terms of impoverishment and catastrophe. 


\section{INSERT TABLE 1}

On the other hand, the original implementation of the DA was designed to be progressive, where people with level III dependency should have benefitted from the DA in 2007; those with level II should have benefitted in 2008-2011, and people with level I in 2012-2015. However, the structural legislation previously cited postponed the inclusion of people with moderate dependence (level I) until July 2015 [45, 46].

The aim of this paper is to estimate the amount of OOP payment for LTC made by users in accordance with the 2012 legislation, and to analyze the effect of this amendment in terms of the impoverishment and catastrophism of households in Spain. The paper is organized as follows: In the second section, we present the databases used in the analysis and the methodology employed to calculate OOP payment, impoverishment and catastrophic expenditure in households. The third section presents the empirical results. The final section is devoted to a discussion of the results obtained and the main conclusions.

\section{Material And Methods}

\section{Sample}

The Spanish Disability and Dependency Survey for 2008 (SDDS) conducted by the Spanish National Statistics Institute [47] was used to obtain the socioeconomic, demographic and health profile and the characteristics of the environment of people with disabilities in Spain. Specifically, we used the households section of the SDDS, which contains surveys on 22,975 persons. The methodology of the survey assigns weights to each item so as to extrapolate the findings to the population with disabilities in Spain. Apart from information related to disabilities, impairments and limitations, it also contains information on the income and financial situation of persons with disabilities, a variable required to calculate the OOP payment corresponding to each dependent person. The sample was projected from 2008 to 2012, applying the weights of situations of dependence by level and autonomous community, and considering the 2012 population data.

\section{Levels of dependence}

The first step was to classify the persons with disability into the levels of dependence defined in the DA. The DA defined three levels of dependency: mild (level I), moderate (level II) and severe (level III). To this end, we compared the level of support required to perform basic and instrumental activities of daily living included in the SDDS with the evaluation scale [48] set out in the DA. The final score used to assign the levels of dependence is the result of adding the product of the basic activities of daily living' tasks requiring support, weighted by the weight of each activity in the overall calculation and the level of support required by each individual. The final score can range from 0 to 100 points: between 0 and 24 points, not elegible; 25 to 49 points, mild level; 50 to 74 , moderate level and 75 to 100 , severe level. This 
methodology is similar to that used in previous studies $[49,50]$ and can be summarized as follows (equation 1).

$\sum \mathrm{i}=1$ nti(a1ie-a2ie-1)

[1]

Where i denotes task for which the individual has difficulty $(n=52)$

$t_{i}=$ weight of the task

$s_{i}=$ level of support required by each individual: partial supervision, $0.90 ;$ maximun supervision, 0.95 and special supervision, 1 .

$a_{1}=$ weight assigned to the activity in the case of mental illness

$a_{2}=$ weight assigned to the activity in the case of no mental illness

$\mathrm{e}=0$ if the individual does not suffer mental illness

$\mathrm{e}=1$ if the individual suffers mental illness

At this point, we established two scenarios. The first scenario was designed as a partial application of DA, including individuals with dependency levels II and III. The second scenario adds individuals with dependency level I, showing a complete application of DA.

\section{OOP payments associated with LTC}

The second step was to calculate beneficiary's OOP payments. To do it, previously it is necessary to identify the cost of the service they receive. Services included residential care, day/night care and home help services. In the case of cash benefits, linked to services, referred to payments to family caregivers and support for non-professional caregivers and personal assistance.

\section{INSERT TABLE 2}

The economic cost of each service is shown in Table 2. We assumed common prices in all the regions of Spain given that the national regulations provide for reference prices for the cost of the services and benefits included in the Act. In this sense, the possible differences across autonomous communities are on the mean. Services were valued in accordance with current legislation [45]. The mean interval of cost was used as defined in the DA for residential care, i.e. $€ 1,350 /$ month, subject to an increase of $40 \%$ to $€ 1,890 /$ month, as set out in the law, in level III cases, which require permanent help for basic activities of daily living. Following the same criterion for day/night care center services, the cost for levels I and II was $€ 650 /$ month, increasing by $25 \%$ to $€ 812.5 /$ month for level III cases. Finally, in the valuation of home help 
benefit, we used the mean interval of hours as defined in the Act [51], which was 10,33 and 58 hours/month for levels I, II and III, respectively. Regarding the cost per hour of this service, as the distribution of services did not provide information on the number of hours dedicated to personal care and home help, the cost of which was $€ 14 /$ hour and $€ 9 /$ hour, respectively, we calculated the cost by using the mean cost of both services, i.e. €11.5/hour.

Cash benefits are different to services in that dependent person does not have to pay previously, but rather a transfer of revenue to the household. In order to calculate the cost of economic benefits relating to services and personal care, the end service was considered to usually be residential care, day/night center and home help. Given the lack of official public statistics, the reference for the service cost was calculated using as weighting factor the weight of the cost of each service in the total cost of services according to level of dependence and autonomous community of residence. To calculate the cost of personal care, home help services were used as the proxy asset.

Regarding cash benefits for family care, the cost was estimated using the cost-replacement method [5254]. Drawing on the information provided by the SDDS-08, we calculated the weekly hours of informal care received by dependent persons according to their level of dependence and autonomous community of residence [55], limited to a maximum of 16 hours per day [56-58]. In order to value each hour, we used the minimum salary of domestic workers [59], which was €5.02/hour.

\section{INSERT TABLE 3}

The OOP payment of each type of benefit was calculated in accordance with legal definition [45]. Calculations are shown in Table 3. The economic capacity of beneficiaries was calculated in accordance with the criteria set out in the DA, although only income was taken into account, as the SDDS provides no information on family assets. In the case of benefits for services the corresponding calculation was applied, while for cash benefits, OOP payment was calculated as the difference between the cost of the service (benefit linked to the service and personal care) or the care (benefit for family care and support for non-professional caregivers) and the amount of the assigned benefit, calculated on the basis of the provisions laid out by the Act.

\section{Impoverishment and catastrophic measures}

Once the OOP payment is estimated, the aim is to identify to what extent this OOP payment affects the impoverishment or catastrophic expenditure of families. To this end, we used the measures of impoverishment and catastrophe defined by Wagstaff and Van Doorslaer (2003) [21]. The impoverishment rate refers to the number of households whose equivalent income $\left(\mathrm{x}_{\mathrm{i}}\right)$ is below the socalled poverty threshold. The equivalent income household was calculated as the relation between the household income and the number of equivalent members or consuming units $\left(\mathrm{n}_{\mathrm{i}}^{\prime}\right)$. To do this, we used the OECD modified equivalence scale [60,61], which assigns a value of 1 to the first household member; 
0.5 to each household member aged 14 or over; and 0.3 to each member aged 13 or under. The poverty threshold is defined as a certain level of income, which in this study was fixed as $60 \%$ of the mean equivalent household income in Spain, based on the Life Conditions Survey $[21,62,63]$. The poverty threshold for 2012 was calculated to be $€ 7,166 /$ year, i.e. $€ 597.17 /$ month.

To analyze the impoverishing impact of OOP payment, we defined two indicators: the pre-payment poverty rate $\left(\mathrm{H}^{\mathrm{pre}}\right)$, that is, before any OOP payment was implemented, and the post-payment poverty rate $\left(\mathrm{H}^{\text {post }}\right)$, that is once the OOP payment was implemented. The pre-payment poverty rate $\left(\mathrm{H}^{\text {pre }}\right)$ corresponds to households which, before making the OOP payment for dependent care, have an equivalent income below the defined threshold. The post-payment poverty rate $\left(\mathrm{H}^{\text {post }}\right)$ was calculated by subtracting the amount of household income, the OOP payment for dependent care, thus establishing their net equivalent income $\left(x_{i}^{\prime}\right)$.

Both indicators, $\mathrm{H}^{\text {pre }}$ and $\mathrm{H}^{\text {post }}$, permit a vision of the two aspects of the impoverishing impact of OOP payment of dependent care: incidence and intensity. On one hand, the difference between the poverty rate before and after OOP payment $\left(\mathrm{H}^{\text {post }}\right)-\left(\mathrm{H}^{\text {pre }}\right)$, shows the incidence of OOP payment, that is, the number of households below the poverty threshold due to OOP payments of dependent care, which had not initially been poor. On the other hand, it shows the increase in the intensity of the poverty gap in households which were already classed as poor. In this way, a household whose net equivalent income is below the poverty threshold is considered a poor household and the difference between the two incomes is defined as the poverty gap for each household. Thus, the sum of the individual poverty gaps forms the overall poverty gap. Ultimately, we have the overall poverty gap of households that were poor before the OOP payment of dependent care; the poverty gap for households that falling below the poverty threshold due to making dependent care OOP payment (it is to say, the poverty gap due to making the OOP payment); and lastly, the poverty gap of new poor households falling beloww the poverty threshold due to making the dependent care OOP payment. The last two measures represent the overall poverty gap due to OOP payment of dependent care.

In the same way as health care OOP payments, those for long-term care can also represent a catastrophic expenditure for households if they force individuals or households to suffer a drop in the standards of living now, or in the future $[18,64]$. The catastrophe threshold $\left(z_{\text {cat }}\right)$ has been defined as a certain percentage of $\left(\mathrm{x}_{\mathrm{i}}\right)$ which households must devote to making the corresponding OOP payment for dependent care, $\left(\mathrm{oop}_{\mathrm{i}}\right)$, in such a way that when a household has to make a payment above the regulatory percentage, this household is classified as catastrophic. The catastrophe incidence has been defined in terms of the percentage by which the OOP payment of dependent care exceeds the catastrophic threshold $\left(\mathrm{z}_{\mathrm{cat}}\right)$, and the mean monthly catastrophic gap has been defined as the amount of income exceeding the catastrophic threshold that is destined to the OOP payment of dependent care. The overall catastrophic gap is the sum of the individual catastrophic gaps. 
Although setting a cut-off point is arbitrary since a small payment may be catastrophic for a poor household, in the literature, these thresholds range from $5 \%$ to $40 \%[18,21,22,63,65]$. In order to analyze the sensitivity of our calculations the regulatory percentages used were $10 \%, 20 \%, 30 \%$ and $40 \%$.

Both the costs of services and the income of the dependent persons are restated to values in euros of 2012, using the Consumer Price Index as restatement factor [66]. The monthly income variable was valuated for each individual and multiple imputation was conducted to estimate missing data [67].

\section{Results}

\section{INSERT TABLE 4}

Table 4 shows the sociodemographic information of the study sample. More than two thirds of the dependent persons are women $(68.41 \%, 67.18 \% \%$ and $68.08 \%$ for levels I, II and III, respectively). The mean age ranges from 70.74 years (DT: 18.00) for level I to 75.52 (DT: 20.03) for level III. The predominant marital status in persons with level I dependence is married (44.64\%), while in levels II and III widowed is the predominant status ( $42.33 \%$ and $48.12 \%$, respectively). In all levels the marital status of separated is the least common. Regarding educational level, for all levels of dependence unfinished primary education is the most common $(55.96 \%, 60.27 \%$ and $66.12 \%$, levels I, II and III, respectively). Between $79.06 \%$ (level I) and $86.97 \%$ (level III) of the dependent persons report their only economic activity to be receiving a pension (contributory or otherwise). The mean number of persons per household is 2.8 in the case of level 1 dependent persons, 2.92 for level II and 3.11 for level III. These figures are lower in the case of equivalent members $(1.82,1.93$ and 2.03 , respectively). Finally, mean monthly income ranges from $€ 1,375.29$ (SD: 1,023.72) for grade I to $€ 1,516.46$ (SD: $1,108.97$ ) for level III.

\section{Table 5. Dependent care OOP payments by level.}

\begin{tabular}{lcccccc} 
& \multicolumn{2}{c}{ LEVEL I } & \multicolumn{2}{c}{ LEVEL II } & \multicolumn{2}{c}{ LEVEL III } \\
\hline & Mean & SD & Mean & SD & Mean & SD \\
Amount & 303.64 & 173.89 & 412.12 & 192.71 & 661.62 & 221.70 \\
\hline$\%$ / total cost benefits & $55.23 \%$ & $18.59 \%$ & $52.98 \%$ & $20.56 \%$ & $52.43 \%$ & $16.28 \%$ \\
\hline$\%$ s/ household income & $31.85 \%$ & $24.21 \%$ & $44.83 \%$ & $35.63 \%$ & $64.95 \%$ & $45.61 \%$
\end{tabular}

Table 5 shows the mean amount a dependent person has to pay depending on their level of dependence: these amounts range from $€ 303.64$ in the case of level I to $€ 661.62$ for level III. This means that dependent persons pay more than $50 \%$ of the cost of their dependent benefit at all three levels. Specifically, level I dependent persons devote a third of their income to this payment (31.85\%), level II, almost half (44.83\%), and level III, almost two-thirds (64.95\%).

The OOP payment of dependent care has an impoverishing impact on dependent persons. Tables 6 and 7 show both scenarios, partial and complete, and reveal that OOP payment generates an impoverishment rate ranging from $19.16 \%$ (level I) to $27.54 \%$ (level III); in other words, these are households which newly 
fall below the poverty threshold after making the OOP payment. Furthermore, we have those households already below the threshold before making the OOP payment $(46.27 \%$ for level I, and $45.84 \%$ for levels II and III). The mean monthly poverty gap per new poor household amounts to €206.52 (SD: 177.97), $€ 283.15$ (SD: 171.98) and €507.15€ (SD: 249.41) for levels I, II y III, respectively, while in the case of the initially poor households the poverty gap increases by €286.76 (SD: 144.21) for level I, €451.76 (SD: 170.04) for level II and €667.10 (SD: 177.64) for level III.

\section{Table 6. Impoverishment rate of dependent care 00P payments by level. Scenario 1 (partial application, including levels II and III).}


Poverty rate

Pre-OOP

payment

$45.84 \%$

$45.84 \%$

$45.84 \%$

(Hpre)

Post-OOP

$68.97 \%$

$73.38 \%$

$70.75 \%$

(Hpost)

$23.13 \%$

$27.54 \%$

$24.91 \%$

Mean

household

poverty gap

(€/month)

(SD)

Pre-OOP

payment

$330.90(277.37) \quad 348.77(294.87)$

$338.12(284.71)$

(Hpre pov)

Increase already poor

$451.76(170.04)$

$667.10(177.64)$

$538.82(202.85)$

households

Increase

$283.15(171.98)$

$507.15(249.41)$

$383.25(237.82)$

poor

households

due to OOP

payments

TOTAL LEVELS II AND III

"A" (M euros

$747,520,920$

$534,722,160$

$1,282,243,080$

per year)

"B" (M euros

per year)

"C" (M euros

per year)

Increase

$1,020,556,800$

$1,022,768,880$

$2,043,325,680$

$322,771,200$

$467,076,120$

$789,847,320$

$1,343,328,000$

$1,489,845,000$

$2,833,173,000$
A as \% (A+
$35.75 \%$
$26.41 \%$
$31.16 \%$
$\mathrm{B}+\mathrm{C})$
$\mathrm{B}$ as \% (A +
$48.81 \%$
$50.52 \%$
$49.65 \%$
$\mathrm{B}+\mathrm{C})$
$\mathrm{C}$ as \% $(\mathrm{A}+$
$15.44 \%$
$23.07 \%$
$19.19 \%$
$\mathrm{B}+\mathrm{C})$
B as \% (B +
C)
C as \% (B +
$75.97 \%$
$68.65 \%$
$72.12 \%$
C)
$24.03 \%$
$31.35 \%$
$27.88 \%$

\section{Table 7. Impoverishment rate of dependent care OOP payments by level. Scenario 2 (complete application, including levels I, II and III).}


Poverty rate

Pre-OOP payment (Hpre)

Post-OOP payment (Hpost)

Increase
$46.27 \%$

$65.44 \%$

$19.16 \%$
$45.99 \%$

$68.91 \%$

$22.92 \%$

Mean household poverty gap ( $€ /$ month)

(SD)

Pre-OOP payment (Hpre pov)

290.50

(266.86)

Increase already poor households

Increase poor households due to OOP payments

286.76

(144.21)

206.52

(177.97)
$321.53(279.54)$

450.99 (220.19)

332.08 (236.18)

TOTAL THREE LEVELS

"A" (M euros per year)
"B" (M euros per year)
"C" (M euros per year)
Increase

$A$ as $\%(A+B+C)$

$\mathrm{B}$ as $\%(\mathrm{~A}+\mathrm{B}+\mathrm{C})$

$\mathrm{C}$ as $\%(\mathrm{~A}+\mathrm{B}+\mathrm{C})$

$\mathrm{B}$ as $\%(\mathrm{~B}+\mathrm{C})$

$\mathrm{C}$ as \% $(\mathrm{B}+\mathrm{C})$
$589,132,680$

$581,546,520$

$173,440,200$

$754,986,720$

$43.83 \%$

$43.27 \%$

$12.90 \%$

$77.03 \%$

$22.97 \%$
$1,871,375,760$

$2,624,872,200$

$963,287,520$

$3,588,159,720$

$34.28 \%$

$48.08 \%$

$17.64 \%$

$73.15 \%$

$26.85 \%$

In terms of aggregate values, this implies that the poverty gap due to OOP payment of dependent care of all households below the poverty threshold amounts to $€ 2,833.2$ million only for levels II and III, and totally for three levels for the second scenario (when level I is included) increase by $26.65 \%$, to $€ 3,588.2$ million $(B+C)$ : of which $€ 963.3$ million corresponds to new poor households (C), and $€ 2,624.9$ to already poor households (B). Consequently, the final poverty gap, including the pre- and post- OOP payment amounts, for the total of the three levels is $€ 5,460.5$ million ( $€ 4,115.4$ million only for levels II and III). This means that the poverty gap before making the dependent care OOP payment $(A)$ accounted for $31.16 \%$ for scenario one and $34.28 \%$ for the second scenario of the final poverty gap, $49.65 \%$ and $48.08 \%$, respectively for scenarios one and two, of which is due to the increase in the intensity of impoverishment of already poor households after payment. The remaining $19.19 \%$ and $17.64 \%$ is the gap corresponding to the households that fall below the poverty threshold because of making the OOP payment, for first and second scenarios, respectively. Furthermore, it can be seen that the intensity of impoverishment is higher for households that were already poor before payment (72.12\% first scenario; $73.15 \%$ second scenario) than for new poor households (27.88\% first scenario; $26.85 \%$ second scenario).

\section{Table 8. Catastrophic effect of dependent care OOP payments by level. Scenario 1 (partial application, including levels II and III).}




\begin{tabular}{|c|c|c|c|c|}
\hline & \multicolumn{4}{|c|}{ Catastrophe threshold $\left(\mathrm{z}_{\mathrm{cat}}, \mathrm{OOP}\right.$ payment as \% of income) } \\
\hline & $10 \%$ & $20 \%$ & $30 \%$ & $40 \%$ \\
\hline LEVEL II & & & & \\
\hline $\begin{array}{l}\text { \% households } \\
\text { with catastrophic } \\
\text { expenditure } \\
\text { (Hcat) }\end{array}$ & $81.19 \%$ & $72.07 \%$ & $64.14 \%$ & $51.45 \%$ \\
\hline $\begin{array}{l}\text { Mean monthly } \\
\text { catastrophe gap } \\
\text { (\%) (SD) }\end{array}$ & $\begin{array}{c}43.72 \% \\
(33.80 \%)\end{array}$ & $\begin{array}{c}38.80 \% \\
(32.51 \%)\end{array}$ & $\begin{array}{c}32.81 \% \\
(32.25 \%)\end{array}$ & $\begin{array}{c}29.51 \% \\
(32.67 \%)\end{array}$ \\
\hline $\begin{array}{l}\text { Mean monthly } \\
\text { catastrophe gap } \\
\text { (euros) (SD) }\end{array}$ & $\begin{array}{c}354.98 \\
(170.69)\end{array}$ & $\begin{array}{c}290.23 \\
(143.52)\end{array}$ & $\begin{array}{c}221.90 \\
(130.63)\end{array}$ & $\begin{array}{c}172.93 \\
(119.61)\end{array}$ \\
\hline $\begin{array}{l}\text { Overall } \\
\text { catastrophe gap } \\
\text { (M euros per } \\
\text { year) }\end{array}$ & $1,420,472,400$ & $1,030,801,080$ & $701,391,241$ & $438,495,000$ \\
\hline LEVEL III & & & & \\
\hline $\begin{array}{l}\text { \% households } \\
\text { with catastrophic } \\
\text { expenditure } \\
\text { (Hcat) }\end{array}$ & $97.27 \%$ & $83.40 \%$ & $72.14 \%$ & $68.07 \%$ \\
\hline $\begin{array}{l}\text { Mean monthly } \\
\text { catastrophe gap } \\
\text { (\%) (SD) }\end{array}$ & $\begin{array}{c}56.54 \% \\
(45.24 \%)\end{array}$ & $\begin{array}{c}55.08 \% \\
(43.29 \%)\end{array}$ & $\begin{array}{c}52.93 \% \\
(41.33 \%)\end{array}$ & $\begin{array}{c}45.84 \% \\
(40.75 \%)\end{array}$ \\
\hline $\begin{array}{l}\text { Mean monthly } \\
\text { catastrophe gap } \\
\text { (euros) (SD) }\end{array}$ & $\begin{array}{c}526.55 \\
(239.06)\end{array}$ & $\begin{array}{c}470.13 \\
(205.78)\end{array}$ & $\begin{array}{c}421.71 \\
(156.62)\end{array}$ & $\begin{array}{c}341.66 \\
(137.48)\end{array}$ \\
\hline $\begin{array}{l}\text { Overall } \\
\text { catastrophe gap } \\
\text { (M euros per } \\
\text { year) }\end{array}$ & $1,713,004,800$ & $1,311,272,400$ & $1,017,454,560$ & $777,759,480$ \\
\hline $\begin{array}{l}\text { Overall } \\
\text { catastrophe gap } \\
\text { level II + level III } \\
\text { (M euros per } \\
\text { year) }\end{array}$ & $3,133,477,200$ & $2,342,073,480$ & $1,718,845,801$ & $1,216,254,480$ \\
\hline
\end{tabular}

\section{Table 9. Catastrophic effect of dependent care OOP payments by level. Scenario 2 (complete application, including levels I, II and III).}




\begin{tabular}{|c|c|c|c|c|}
\hline & \multicolumn{4}{|c|}{ Catastrophe threshold ( $\mathrm{z}_{\text {cat }}$, OOP payment as \% of income) } \\
\hline & $10 \%$ & $20 \%$ & $30 \%$ & $40 \%$ \\
\hline LEVEL I & & & & \\
\hline $\begin{array}{l}\% \text { households } \\
\text { with catastrophic } \\
\text { expenditure } \\
\text { (Hcat) }\end{array}$ & $83.43 \%$ & $69.23 \%$ & $41.68 \%$ & $23.84 \%$ \\
\hline $\begin{array}{l}\text { Mean monthly } \\
\text { catastrophe gap } \\
\text { (\%) (SD) }\end{array}$ & $\begin{array}{c}27.06 \% \\
(23.20 \%)\end{array}$ & $\begin{array}{c}21.58 \% \\
(22.96 \%)\end{array}$ & $\begin{array}{c}22.52 \% \\
(23.84 \%)\end{array}$ & $\begin{array}{c}26.61 \% \\
(22.89 \%)\end{array}$ \\
\hline $\begin{array}{l}\text { Mean monthly } \\
\text { catastrophe gap } \\
\text { (euros) (SD) }\end{array}$ & $\begin{array}{c}224.71 \\
(157.00)\end{array}$ & $\begin{array}{c}157.91 \\
(145.78)\end{array}$ & $\begin{array}{c}144.32 \\
(138.88)\end{array}$ & $\begin{array}{c}153.78 \\
(114.48)\end{array}$ \\
\hline $\begin{array}{l}\text { Overall } \\
\text { catastrophe gap } \\
\text { (M euros per } \\
\text { year) }\end{array}$ & $821,657,400$ & $479,111,760$ & $263,643,960$ & $160,647,960$ \\
\hline $\begin{array}{l}\text { Overall } \\
\text { catastrophe gap } \\
\text { level I + level II + } \\
\text { level III (M euros } \\
\text { per year) }\end{array}$ & $3,955,134,600$ & $2,821,185,240$ & $1,982,489,761$ & $1,376,902,440$ \\
\hline
\end{tabular}

Tables 8 and 9 show the catastrophic expenditure effects of paying dependent care OOP payments. It can be seen that more than $80 \%$ of households dedicate more than $10 \%$ of their income to dependent care OOP payment, specifically $83.43 \%$ in the case of level I, $81.19 \%$ for level II and $97.27 \%$ for level III. The mean monthly catastrophe gaps by level are $€ 224.71$ (SD: 157.00) for level I, €354.98 (SD: 170.96) for level II and €526.55 (SD: 239.06) for level III. These percentages and amounts decrease as the cut-off thresholds used increase. Thus, it can be seen that the percentage of households devoting more than $40 \%$ of their income to funding dependent care benefits is $23.84 \%$ for level I, $51.45 \%$ for level II and $68.07 \%$ for level III, with a mean monthly catastrophe gap of $€ 153.78$ (SD: 114.48), €172.93 (SD: 119.61) and €341.66 (SD: 137.48), respectively.

In annual terms, the catastrophe gap generated by devoting more than $10 \%$ of the household income to dependent care OOP payment reaches $€ 3,133.5$ million $(0.30 \%$ of GDP) for scenario 1 (i.e., both levels II and III), and $€ 3,955.1$ million ( $0.38 \%$ of GDP) for the second scenario (three levels). This amount decreases for levels II and III to €2,342.1 million ( $0.22 \%$ of GDP), $€ 1,718.9$ million ( $0.18 \%$ of GDP) and $€ 1,216.3$ million $(0.11 \%$ of GDP) for catastrophe thresholds of $20 \%, 30 \%$ and $40 \%$, respectively. This values increase when level I is included, to $€ 2,821.2$ million ( $0.27 \%$ of GDP), $€ 1,982.5$ million $(0.19 \%$ of GDP) and $€ 1,376.9$ million $(0.13 \%$ of GDP) for catastrophe thresholds of $20 \%, 30 \%$ and $40 \%$, respectively.

\section{Discussion}

The current work analyses the economic impact of dependent care OOP payment in Spain on the finances of dependent persons.

The recession in which Spain has been immersed since 2007 and the fiscal cutbacks implemented have acted as a brake on the expectations for access of dependent persons set out in the 2006 DA [68]. In fact, the modifications to the DA correspond to the third phase of the Spanish financial crisis (2011Q1-2013Q4), which was the period of the most acute economic contraction, characterized by wide-ranging, severe fiscal and structural measures [69]. In this sense, two consequences can be seen: on one hand, there has been a lack of transfer form informal to formal care, and on the other, the OOP payment to be made by 
dependent persons increased in a scenario of falling income and an excess of household debt, especially in the lowest-earning families [70].

Our results show that a dependent person has a mean monthly expenditure ranging from $€ 309.19$ for level I dependence to $€ 658.06$ for level III. This means that dependent persons are contributing between one- and two-thirds of their income to paying more than $50 \%$ of the cost of the services they receive. These figures are far from the initial objectives of the DA, which provided for the cost being proportionally shared by the user, the regional government and the national government. The higher user contribution means that the financial risk for households with dependent persons is increasingly higher.

Our work, in the same vein as studies assessing the impoverishing impact of health care OOP payment, examines the catastrophic and impoverishing effects of OOP payment of long-term care. Expenditure on the OOP payment of long term care has a major impact on households with dependent persons in Spain, since one in five households in the case of level I and one of four in the case of levels II and III (23.13\% and $27.54 \%)$ fall below the poverty threshold after making the OOP payment. This impoverishing impact of OOP payment is also found for health care OOP payment in previous studies, albeit in lower percentages $[7,18,19,21,22,65]$.

The impoverishing impact of OOP payment differs according to the level of dependence. The most affected are those with level III dependence, which creates an additional problem since, in the case of level III dependent persons, even though their contributions increase, the demand for the services they receive does not decrease, due to its inelastic nature.

In terms of catastrophic expenditure, the pattern of behavior is repeated: more than $80 \%$ of households dedicate $10 \%$ of their resources to paying the cost of dependence, which represents $€ 3,955.1$ million ( $0.38 \% \mathrm{GDP}$ ) if level I is included, $3,133.5$ only for levels II and III $(0.30 \% \mathrm{GDP})$. Although as the catastrophe threshold increases, the percentage of households in a catastrophic situation decreases, it is significant that more than half of in the case of level II and two-thirds in that of level III devote more than $40 \%$ of their income to dependent care OOP payment.

In terms of aggregate values, Spanish households below the poverty threshold pay a total of more than $€ 3,588.2$ million in dependent care OOP payments. This means that if Spanish public authorities wish to prevent the impoverishment of households with dependent persons, they have to increase their contribution to funding dependent care by that amount.

The likelihood of households with dependent persons falling below the catastrophe threshold may be due to two factors: either because a household with limited economic resources has to make a small payment, or because a household with sufficient resources has to satisfy a large OOP payment. The drafting of the law apparently considered both questions in its provisions for OOP payment. However, the data confirm impoverishment and risk of catastrophic expenditure in households. Drawing on Blomqvist and Busby (2012) [71], the authorities should consider reducing or eliminating OOP payment if users' incomes fall below a determined level, which could be taken as the poverty threshold.

Following the legislation implemented in 2012, the funding of dependent care causes a risk of impoverishment and catastrophic expenditure as reflected in the percentages of OOP payments of over $50 \%$. This finding coincides with the results of the study on health care OOP payments conducted by Xu et al. (2007) [7]. Hence, several proposals need to be made. Besides associating OOP payments with the user's income, exemption form OOP payment should be considered for certain levels of dependence. In addition, thought could be given to the implementation of a funding regime before the situation for dependence arises; in other words, a private health insurance system. As suggested by Mclntyre (2006) [19], health insurance could be more appropriate for avoiding the risk of impoverishment. Although funding systems would depend on the institutional structures, culture, traditions and economic development of each individual country, alternatives need to be found which avoid situations of catastrophic expenditure. 
There are two main limitations of the study. Firstly, while the 2008 Spanish Disability and Dependency Survey was taken as the basis for the socio-demographic characteristics of the dependent population, the copayment for LTC services was calculated according to the 2012 Dependency Act. Nevertheless, the results should not be greatly affected by this lag in the data sources, since the evolution in the prevalence of disability tends to remain unchanged over time [43]. For instance, in Spain the prevalence of disability amounted to $6.2 \%$ in 1999 and $6.5 \%$ in 2008 , while that of long term care increased only from $4.4 \%$ to $5.1 \%$ in the same time period [72].

\section{Conclusion}

Our results make various contributions to empirical research on the effect of OOP payment on long-term care in terms of impoverishment and catastrophic expenditure in Spain. The study presents measures of impoverishment and catastrophe related to long-term health care expenditure; it analyses the consequences of the 2012 OOP payment reform on Spanish households; it quantifies the households which are poorer as a consequence of OOP payment or which are poor following the OOP payment reform and those which OOP payment has left in a catastrophic situation.

To the best of our knowledge, this is the first work to analyze the impoverishing impact of dependent care OOP payments in Spain and it contributes to understanding of the economic burden of OOP. The calculation of the monetary amount of OOP payment could be a limitation of the work.

Our results should serve to develop strategies for protection against the financial risk resulting from facing the costs of a situation of dependence. The drafters of future laws might consider a system with exemptions more closely related to families' incomes. Furthermore, it seems reasonable that political decision makers should implement policies to reduce social imbalance, in this case, alleviating the financial impact on persons with dependence and providing them with services appropriate to their needs.

\section{Abbreviations}

OOP: out-of-pocket; LTC: long-term care; Dependency Act: DA

\section{Declarations}

\section{Ethics approval and consent to participate}

Not applicable

\section{Consent for publication}

Not applicable

\section{Availability of data and material}

Available in:

http://www.ine.es/dyngs/INEbase/es/operacion.htm?c = Estadistica_C\&cid = $1254736176782 \&$ menu $=$ resultados $\&$ secc $=1254736195313 \& \mathrm{idp}=1254735573175$, and please contact author for data requests 


\section{Competing interests}

The authors declare that they have no competing interests.

\section{Funding}

Study was funded by the XXXIII Edition Grant Spanish Asociation of Health Economics and Bayer HealthCare and the Spanish State Programme of R+D+I (ECO2017-83771-C3-1-R).

\section{Authors' contributions}

All authors designed and managed the study. RPR carried out the data preparation and the statistical analysis. FES and IPG have contributed in writing the first draft of the manuscript. All the authors have provided input on multiple drafts of the manuscript and approval of the final version.

\section{Acknowledgements}

Not applicable

\section{Authors' information (optional)}

\section{Tables}

\section{Table 1. Increased in out-of-pocket payment associated with LTC in Spain.}




\begin{tabular}{|c|c|c|c|c|}
\hline & & Legislation & \multicolumn{2}{|c|}{ Legislation post-crisis** } \\
\hline & & $\begin{array}{l}\text { Level I / } \\
\text { Level II / } \\
\text { Level III } \\
\end{array}$ & $\begin{array}{l}\text { Level I / } \\
\text { Level II }\end{array}$ & Level III \\
\hline \multirow[t]{7}{*}{$\begin{array}{l}\text { In-kind } \\
\text { services }\end{array}$} & Residential Care & $\begin{array}{l}70-90 \% \\
\text { Economic } \\
\text { capacity of } \\
\text { beneficiary }\end{array}$ & $\begin{array}{c}\text { If monthly } \\
\text { income < } \\
532.51=> \\
\text { OOP }=0\end{array}$ & $\begin{array}{c}\text { If monthly } \\
\text { income < } \\
532.51=> \\
\text { OOP }=0\end{array}$ \\
\hline & & & $\begin{array}{c}\text { If monthly } \\
\text { income } \\
>1,541.18 \\
=>\text { OOP }= \\
1,440\end{array}$ & $\begin{array}{c}\text { If monthly } \\
\text { income } \\
>2,117.18=> \\
\text { OOP }=2,016\end{array}$ \\
\hline & $\begin{array}{l}\text { Day / Night Care } \\
\text { Center }\end{array}$ & $\begin{array}{c}10-65 \% \\
\text { Economic } \\
\text { capacity of } \\
\text { beneficiary }\end{array}$ & $\begin{array}{c}\text { If monthly } \\
\text { income < } \\
532.51=> \\
\text { OOP }=0\end{array}$ & $\begin{array}{c}\text { If monthly } \\
\text { income < } \\
532.51=> \\
\text { OOP }=0\end{array}$ \\
\hline & & & $\begin{array}{c}\text { If monthly } \\
\text { income } \\
>1,842.28 \\
=>\text { OOP }= \\
585\end{array}$ & $\begin{array}{c}\text { If monthly } \\
\text { income } \\
>2,207.91=> \\
\text { OOP }=731.25\end{array}$ \\
\hline & Home Help Services & $\begin{array}{c}10-65 \% \\
\text { Economic } \\
\text { capacity of } \\
\text { beneficiary }\end{array}$ & \multirow{2}{*}{$\begin{array}{c}\text { If monthly } \\
\text { income < } \\
532.51=> \\
\text { OOP }=20 \\
\text { If monthly } \\
\text { income } \\
>1,842.28 \\
=>00 P= \\
567\end{array}$} & \multirow{2}{*}{$\begin{array}{c}\text { If monthly } \\
\text { income < } \\
532.51=> \\
\text { OOP }=20 \\
\text { If monthly } \\
\text { income } \\
>2,207.91=> \\
\text { OOP }=882\end{array}$} \\
\hline & & & & \\
\hline & & & \begin{tabular}{l|l} 
Level I & L \\
\end{tabular} & \begin{tabular}{l|l} 
el & Level IIi \\
\end{tabular} \\
\hline \multirow[t]{3}{*}{$\begin{array}{l}\text { Cash } \\
\text { Benefits }\end{array}$} & Linked to services & $\begin{array}{c}\leq 60 \% \\
\text { Economic } \\
\text { capacity of } \\
\text { beneficiary }\end{array}$ & \multicolumn{2}{|c|}{$\begin{array}{l}* * \text { Depends of the cost of the } \\
\text { service and the economic } \\
\text { capacity of beneficiary }\end{array}$} \\
\hline & $\begin{array}{l}\text { For family care and } \\
\text { help to support for } \\
\text { non professional } \\
\text { caregivers }\end{array}$ & $\begin{array}{c}\leq 75 \% \\
\text { Economic } \\
\text { capacity of } \\
\text { beneficiary }\end{array}$ & \multicolumn{2}{|c|}{$\begin{array}{l}\text { If monthly income }<399.38 \\
=>\mathrm{OOP}=0 \\
\text { If monthly income }>1,609.63 \\
=>\text { OOP }=\text { Maximum, i.e., } \\
\text { cash benefit }=0\end{array}$} \\
\hline & Personal assistance & $\begin{array}{c}\leq 60 \% \\
\text { Economic } \\
\text { capacity of } \\
\text { beneficiary }\end{array}$ & \multicolumn{2}{|c|}{$\begin{array}{l}\text { **Depends on the cost of the } \\
\text { service and the economic } \\
\text { capacity of beneficiary }\end{array}$} \\
\hline
\end{tabular}


* Resolution of 2 December 2008, of the State Secretariat for Social Policy, Families and Dependency and Disability, on the Agreement the Territorial Council for Autonomy and Attention to Dependency, on determining the economic capacity of beneficiaries and the criteria of participation for beneficiaries in the services and benefits provided by the Dependency System

** Resolution of 13 July 2012, of the State Secretariat for Social Services and Equality, on the Agreement the Territorial Council for Autonomy and Attention to Dependency for the improvement of the system for the autonomy and attention of dependent persons.

\section{Table 2. Cost of dependent care benefit by type in euros, 2012.}

\begin{tabular}{|c|c|c|c|}
\hline & LEVEL I & LEVEL II & LEVEL III \\
\hline \multicolumn{4}{|c|}{ SERVICES } \\
\hline RESIDENTIAL & Mean interval: & Mean interval: & Mean interval + \\
\hline CARE & $€ 1,350 /$ month & $€ 1,350 /$ month & $\begin{array}{l}40 \% \text { increase }= \\
€ 1,890 / \text { month }\end{array}$ \\
\hline $\begin{array}{l}\text { DAY/NIGHT } \\
\text { CENTERS }\end{array}$ & $€ 650 /$ month & $€ 650 /$ month & $\begin{array}{l}€ 650 / \text { month }+25 \% \\
\text { increase }= \\
€ 812.5 / \text { month } \\
\end{array}$ \\
\hline \multirow[t]{3}{*}{ HOME HELP } & $\begin{array}{l}\text { Mean hours per } \\
\text { month }=10 \text { hours }\end{array}$ & $\begin{array}{l}\text { Mean hours per } \\
\text { month }=33 \text { hours }\end{array}$ & $\begin{array}{l}\text { Mean hours per } \\
\text { month }=58 \text { hours }\end{array}$ \\
\hline & $\begin{array}{l}\text { Mean cost per } \\
\text { hour }=€ 11.5 / \text { hour }\end{array}$ & $\begin{array}{l}\text { Mean cost per } \\
\text { hour }=€ 11.5 / \text { hour }\end{array}$ & $\begin{array}{l}\text { Mean cost per hour } \\
\quad=€ 11.5 / \text { hour }\end{array}$ \\
\hline & $\begin{array}{l}10 \times 11.5= \\
€ 115 \text { month }\end{array}$ & $\begin{array}{l}33 \times 11.5= \\
€ 379.5 / \text { month }\end{array}$ & $\begin{array}{l}58 \times 11.5= \\
€ 667 / \text { month }\end{array}$ \\
\hline \multicolumn{4}{|c|}{ CASH BENEFITS } \\
\hline \multirow[t]{2}{*}{$\begin{array}{l}\text { LINKED } \\
\text { SERVICES }\end{array}$} & \multicolumn{3}{|c|}{$\begin{array}{l}\text { Cost of service }=w_{1} \text { x cost of residential care level }+w_{2} x \\
\text { cost of day/night centres level }+w_{3} x \text { cost of home help level }\end{array}$} \\
\hline & \multicolumn{3}{|c|}{ 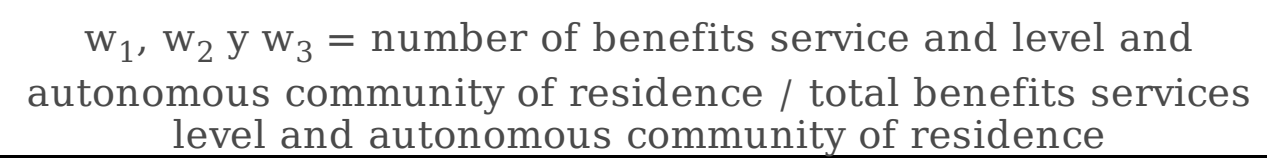 } \\
\hline $\begin{array}{ll}\text { FOR } & \text { FAMILY }\end{array}$ & \multicolumn{3}{|c|}{ Cost of care $=$ mean number of weekly hours informal care by } \\
\hline CARE AND HELP & \multirow{2}{*}{\multicolumn{3}{|c|}{$\begin{array}{l}\text { autonomous community of residence } \mathrm{x} \text { minimum wage } \\
\text { domestic workers (€5.02 hour) } \mathrm{x} 4 \text { weeks } / \text { month }\end{array}$}} \\
\hline TO SUPPORT & & & \\
\hline FOR NON & e.g. National total & e.g. National total & e.g. National total \\
\hline PROFESSIONAL & hours/month $\mathrm{x}$ & hours/month $\mathrm{x}$ & $\begin{array}{l}=50.03 \\
\text { hours/month } \mathrm{x}\end{array}$ \\
\hline CAREGIVERS & $€ 5.02$ /hour x 4 & $€ 5.02$ /hour x 4 & $€ 5.02$ /hour x 4 \\
\hline & $\begin{array}{l}\text { weeks/month }= \\
€ 420.68 / \text { month }\end{array}$ & $\begin{array}{l}\text { weeks } / \text { month }= \\
€ 740.75 / \text { month }\end{array}$ & $\begin{array}{l}\text { weeks/month }= \\
€ 1,117.05 / \text { month }\end{array}$ \\
\hline PERSONAL & Cost of service $=$ & Cost of service $=$ & Cost of service $=$ \\
\hline ASSISTANCE & $\begin{array}{l}\text { home help service } \\
\quad=€ 115 / \text { month }\end{array}$ & $\begin{array}{l}\text { home help service } \\
=€ 379.5 / \text { month }\end{array}$ & $\begin{array}{l}\text { home help service } \\
\quad=€ 667 / \text { month }\end{array}$ \\
\hline
\end{tabular}

\section{Table 3. Beneficiary OOP payments by type of dependent care benefit in euros 2012.}




\begin{tabular}{|c|c|}
\hline & SERVICES \\
\hline \multirow[t]{2}{*}{ RESIDENTIAL CARE } & $\begin{array}{c}\text { OOP payment }=\underset{\text { economic capacity beneficiary }-}{ } \\
\text { MQ }\end{array}$ \\
\hline & $\begin{array}{c}\text { MQ (minimum quantity personal expenses }=0.19 \mathrm{x} \\
\text { IPREM }^{\mathrm{a}} \text { ) }\end{array}$ \\
\hline DAY/NIGHT CENTERS & $\begin{array}{c}\text { OOP payment }=(0.4 \text { x economic capacity } \\
\text { beneficiary })-\left(\text { IPREM }^{\mathrm{a}} / 3,33\right)\end{array}$ \\
\hline \multirow[t]{4}{*}{ HOME HELP } & $\begin{array}{c}\text { Levels I and II: OOP payment }=(0.3333 \mathrm{x} \\
\text { cost/hour x economic capacity beneficiary })-(0.25 \\
\text { x cost/hour })\end{array}$ \\
\hline & $\begin{array}{l}\text { Level III: OOP payment }=(0.4 \times \text { cost } / \text { hour } \mathrm{x} \\
\text { economic capacity beneficiary })-(0.3 \times \text { cost } / \text { hour })\end{array}$ \\
\hline & Mean cost/hour $=€ 11.5 /$ hour \\
\hline & CASH BENEFITS \\
\hline \multirow[t]{5}{*}{ LINKED TO SERVICES } & $\begin{aligned} & \text { OOP payment }= \text { cost of service }- \text { amount of cash } \\
& \text { benefit assigned }\end{aligned}$ \\
\hline & $\begin{array}{c}\text { Amount of cash benefit assigned }=\text { cost of service } \\
+ \text { MQ- economic capacity beneficiary }\end{array}$ \\
\hline & $\begin{array}{c}\text { Level I: } 0<\text { amount of cash benefit assigned }< \\
€ 300 / \text { month }\end{array}$ \\
\hline & $\begin{array}{c}\text { Level II: } 0<\text { amount of cash benefit assigned }< \\
€ 426.12 / \text { month }\end{array}$ \\
\hline & $\begin{array}{c}\text { Levl III: } 0<\text { amount of cash benefit assigned }< \\
€ 715.07 / \text { month }\end{array}$ \\
\hline \multirow{5}{*}{$\begin{array}{lrr}\text { FOR } & \text { FAMILY CARE } & \text { AND } \\
\text { HELP } & \text { TO SUPPORT } & \text { FOR } \\
\text { NON } & \text { PROFESSIONAL } \\
\text { CAREGIVERS }\end{array}$} & $\begin{aligned} & \text { OOP payment }= \text { cost of service }- \text { amount of cash } \\
& \text { benefit assigned }\end{aligned}$ \\
\hline & $\begin{array}{c}\text { Amount of cash benefit assigned }=(1.33 \mathrm{x} \\
\text { maximum amount of benefit })-(0.44 \mathrm{x} \text { economic } \\
\text { capacity beneficiary x maximum amount of benefit }) \\
/ \text { IPREM }^{\mathrm{a}}\end{array}$ \\
\hline & $\begin{array}{c}\text { Level I: } 0<\text { amount of cash benefit assigned }< \\
€ 153 / \text { month }\end{array}$ \\
\hline & $\begin{array}{c}\text { Level II: } 0<\text { amount of cash benefit assigned }< \\
€ 268.79 / \text { month }\end{array}$ \\
\hline & $\begin{array}{c}\text { Level III: } 0<\text { amount of cash benefit assigned }< \\
€ 387.64 / \text { month }\end{array}$ \\
\hline \multirow[t]{5}{*}{ PERSONAL ASSISTANCE } & $\begin{array}{l}\text { Amount of cash benefit }=\text { cost of service }+ \text { MQ- } \\
\text { ECB }\end{array}$ \\
\hline & Cost of service $=$ Cost of home help service \\
\hline & $\begin{array}{c}\text { CM (minimum quantity personal expenses }=0.19 \mathrm{x} \\
\text { IPREM }^{\mathrm{a}} \text { ) }\end{array}$ \\
\hline & $\begin{array}{c}\text { Level I: } 0<\text { amount of cash benefit assigned }< \\
€ 300 / \text { month }\end{array}$ \\
\hline & \\
\hline
\end{tabular}


Level III: 0 < amount of cash benefit assigned < $€ 715.07 /$ month

IPREM $^{\mathrm{a}}$ 2012: €532.51/month. IPREM (Indicador Público de Renta de Efectos Múltiples), Public Multiple Effects Income Indicator, used as a reference for cash benefits and granting financial aid.

\section{Table 4. Sociodemographic variables by level of dependence EDAD-08.}

\begin{tabular}{|c|c|c|c|c|c|c|}
\hline Variables & \multicolumn{2}{|c|}{ LEVEL I } & \multicolumn{2}{|c|}{ LEVEL II } & \multicolumn{2}{|c|}{ LEVEL III } \\
\hline Gender & $\mathrm{N}$ & $\%$ & $\mathrm{~N}$ & $\%$ & $\mathrm{~N}$ & $\%$ \\
\hline Male & 115,355 & $31.59 \%$ & 134,776 & $32.82 \%$ & 88,948 & $31.92 \%$ \\
\hline Female & 249,863 & $68.41 \%$ & 275,927 & $67.18 \%$ & 189,754 & $68.08 \%$ \\
\hline $\begin{array}{l}\text { Age (Mean (SD) } \\
\text { Min - Max) }\end{array}$ & $\begin{array}{c}70.74 \\
(18.00) 6- \\
104\end{array}$ & & $\begin{array}{c}72.95 \\
(18.70) 6- \\
104\end{array}$ & & $\begin{array}{c}75.52 \\
(20,03) 6- \\
102\end{array}$ & \\
\hline Marital status & & & & & & \\
\hline Single & 54,846 & $15.02 \%$ & 66,100 & $16,09 \%$ & 47.495 & $17,04 \%$ \\
\hline Married & 163,029 & $44,64 \%$ & 162,967 & $39,68 \%$ & 93.142 & $33,42 \%$ \\
\hline Widowed & 135,668 & $37.15 \%$ & 173,834 & $42.33 \%$ & 134,110 & $48.12 \%$ \\
\hline Separated & 11,675 & $3.20 \%$ & 7,802 & $1.90 \%$ & 3,955 & $1.42 \%$ \\
\hline Educational level & & & & & & \\
\hline Unfinished Primary & 203,721 & $55.96 \%$ & 247,144 & $60.27 \%$ & 183,435 & $66.12 \%$ \\
\hline Primary & 120,611 & $33.13 \%$ & 122,310 & $29.83 \%$ & 76,746 & $27.66 \%$ \\
\hline Secondary & 22,939 & $6.30 \%$ & 20,091 & $4.90 \%$ & 8,930 & $3.22 \%$ \\
\hline Tertiary & 16,806 & $4.62 \%$ & 20,547 & $5.01 \%$ & 8,323 & $3.00 \%$ \\
\hline Employment status & & & & & & \\
\hline Working & 13,587 & $3.77 \%$ & 5,578 & $1.38 \%$ & 1,011 & $0.37 \%$ \\
\hline Unemployed & 6,865 & $1.91 \%$ & 3,387 & $0.84 \%$ & 1,664 & $0.61 \%$ \\
\hline Receiving pension & 284,757 & $79.06 \%$ & 350,786 & $86.60 \%$ & 236,707 & $86.97 \%$ \\
\hline Other & 54,988 & $15.27 \%$ & 45,326 & $11.19 \%$ & 32,784 & $12.05 \%$ \\
\hline $\begin{array}{c}\text { Number of } \\
\text { members household } \\
\text { (Mean [SD] Min - } \\
\text { Max) }\end{array}$ & $\begin{array}{l}2, .8(1.36) \\
1-11\end{array}$ & & $\begin{array}{c}2.92 \\
(1.39) 1- \\
9\end{array}$ & & $\begin{array}{c}3.11 \\
(1.34) 1- \\
10\end{array}$ & \\
\hline $\begin{array}{c}\text { Number of } \\
\text { equivalent } \\
\text { members household } \\
\text { (Mean [SD] Min - } \\
\text { Max) }\end{array}$ & $\begin{array}{c}1.82 \\
(0.65) 1- \\
5.2\end{array}$ & & $\begin{array}{c}1.93 \\
(0.66) 1- \\
5\end{array}$ & & $\begin{array}{c}2.03 \\
(0.64) 1- \\
5.3\end{array}$ & \\
\hline $\begin{array}{l}\text { Monthly income } \\
\text { (Mean [SD]) }\end{array}$ & $\begin{array}{c}1,375.29 \\
(1,023.72)\end{array}$ & & $\begin{array}{c}1,448.46 \\
(1,071.46)\end{array}$ & & $\begin{array}{l}1,516.46 \\
(1.108 .97)\end{array}$ & \\
\hline
\end{tabular}

\section{References}

[1]Colombo F, Nozal AL, Mercier J, Tjadens F. OECD health policy studies help wanted? Providing and paying for long-term care: providing and paying for long-term care. OECD Publishing, 2011. 
[2]OECD. Health at Glance. 2015.

[3]Agree EM, Glaser K. Demography of informal caregiving. International handbook of population aging: Springer, 2009:647-68.

[4]Esping-Andersen G, Palier B. Los tres grandes retos del Estado del bienestar. Grupo Planeta (GBS), 2010.

[5]González López-Valcárcel B, Rodríguez Feijoó S, Puig-Junoy J. Copagos sanitarios: revisión de experiencias internacionales y propuestas de diseño. Fedea Policy Papers 2016.

[6]Drummond $\mathrm{M}$, Towse A. Is it time to reconsider the role of patient co-payments for pharmaceuticals in Europe? The European Journal of Health Economics 2012; 13:1-5.

[7]Xu K, Evans DB, Carrin G, Aguilar-Rivera AM, Musgrove P, Evans T. Protecting households from catastrophic health spending. Health Aff (Millwood) 2007; 26:972-83.

[8]Main S. Back to Back: Co-payments must go!: Yes. Journal of Primary Health Care 2011; 3:228-30.

[9]Font JC, Toyama MG. Does cost sharing really reduce inappropriate prescriptions among the elderly? Health Policy 2011; 101:195-208.

[10]Farbmacher H, Winter J. Per-Period Co-Payments And The Demand For Health Care: Evidence From Survey And Claims Data. Health Economics 2013; 22:1111-23.

[11]Kowalski A. Censored quantile instrumental variable estimates of the price elasticity of expenditure on medical care. Journal of Business \& Economic Statistics 2016; 34:107-17.

[12]Kiil A, Houlberg K. How does copayment for health care services affect demand, health and redistribution? A systematic review of the empirical evidence from 1990 to 2011 . The European Journal of Health Economics: HEPAC 2014; 15:813.

[13]Sen B, Blackburn J, Morrisey MA, Kilgore ML, Becker DJ, Caldwell C, Menachemi N. Did copayment changes reduce health service utilization among CHIP enrollees? Evidence from Alabama. Health Services Research 2012; 47:1603-20.

[14]Janus AL, Ermisch J. Who pays for home care? A study of nationally representative data on disabled older Americans. BMC Health Services Research 2015; 15:301.

[15]Spector WD, Cohen JW, Pesis-Katz I. Home care before and after the Balanced Budget Act of 1997: shifts in financing and services. The Gerontologist 2004; 44:39-47.

[16]Antonanzas F, Rodríguez-lbeas R. Channeling health economics research initiatives to improve decision-making processes in the EU. The European Journal of Health Economics 2013; 14:847-52.

[17]Tamblyn R, Laprise R, Hanley JA, Abrahamowicz M, Scott S, Mayo N, Hurley J, Grad R, Latimer E, Perreault R. Adverse events associated with prescription drug cost-sharing among poor and elderly persons. JAMA 2001; 285:421-9.

[18]Tomini SM, Packard TG, Tomini F. Catastrophic and impoverishing effects of out-ofpocket payments for health care in Albania: evidence from Albania Living Standards Measurement Surveys 2002, 2005 and 2008. Health Policy and Planning 2012; 28:419-28.

[19]McIntyre D, Thiede M, Dahlgren G, Whitehead M. What are the economic consequences for households of illness and of paying for health care in low-and middle-income country contexts? Social Science \& Medicine 2006; 62:858-65. 
[20]van Doorslaer E, O'Donnell O, Rannan-Eliya RP, Somanathan A, Adhikari SR, Garg CC, Harbianto D, Herrin AN, Huq MN, Ibragimova S, Karan A, Lee TJ, Leung GM, Lu JF, Ng CW, Pande BR, Racelis R, Tao S, Tin K, Tisayaticom K, Trisnantoro L, Vasavid C, Zhao Y.

Catastrophic payments for health care in Asia. Health Economics 2007; 16:1159-84.

[21]Wagstaff A, van Doorslaer E. Catastrophe and impoverishment in paying for health care: with applications to Vietnam 1993-1998. Health Economics 2003; 12:921-34.

[22]Xu K, Evans DB, Kawabata K, Zeramdini R, Klavus J, Murray CJ. Household catastrophic health expenditure: a multicountry analysis. Lancet 2003; 362:111-7.

[23]Himmelstein DU, Warren E, Thorne D, Woolhandler SJ. Illness and injury as contributors to bankruptcy. 2005.

[24]Reed MC, Tu HT. Triple jeopardy: low income, chronically ill and uninsured in America. Issue brief (Center for Studying Health System Change) 2002:1-4.

[25]Hafner-Eaton C. Physician Utilization Disparities Between the Uninsured and Insured: Comparisons of the Chronically III, Acutely III, and Well Nonelderly Populations. JAMA 1993; 269:787-92.

[26]Ferrer RL. Pursuing equity: contact with primary care and specialist clinicians by demographics, insurance, and health status. The Annals of Family Medicine 2007; 5:492502 .

[27]Hoffman C, Schwartz K. Eroding access among nonelderly US adults with chronic conditions: ten years of change. Health Affairs 2008; 27:w340-w8.

[28]Hadley J. Insurance coverage, medical care use, and short-term health changes following an unintentional injury or the onset of a chronic condition. JAMA 2007; 297:107384.

[29]Hanson KW, Neuman P, Dutwin D, Kasper JD. Uncovering the health challenges facing people with disabilities: the role of health insurance. Health Affairs 2003:W3.

[30]Meyer JA, Zeller PJ. Profiles of disability: employment and health coverage. Kaiser Commission on Medicaid and the Uninsured Washington, DC: Henry J Kaiser Family Foundation 1999.

[31]Shin J, Moon S. Quality of care and role of health insurance among non-elderly women with disabilities. Women's Health Issues 2008; 18:238-48.

[32]Perry M, Dulio A, Hanson KW. The Role of Health Coverage for People with Disablities: Findings from 12 Focus Groups with People with Disabilities. Henry J. Kaiser Family Foundation, 2003.

[33]Gulley SP, Altman BM. Disability in two health care systems: access, quality, satisfaction, and physician contacts among working-age Canadians and Americans with disabilities. Disability and Health Journal 2008; 1:196-208.

[34]Choi JW, Choi JW, Kim JH, Yoo KB, Park EC. Association between chronic disease and catastrophic health expenditure in Korea. BMC Health Services Research 2015; 15:26.

[35]Htet S, Alam K, Mahal A. Economic burden of chronic conditions among households in Myanmar: the case of angina and asthma. Health Policy and Planing 2015; 30:1173-83.

[36]Wang Z, Li X, Chen M. Catastrophic health expenditures and its inequality in elderly households with chronic disease patients in China. International Journal for Equity in Health $2015 ; 14: 8$. 
[37]Choi JW, Shin JY, Cho KH, Nam JY, Kim JY, Lee SG. Medical security and catastrophic health expenditures among households containing persons with disabilities in Korea: a longitudinal population-based study. International Journal for Equity in Health 2016; 15:119.

[38]Lee JE, Shin HI, Do YK, Yang EJ. Catastrophic Health Expenditures for Households with Disabled Members: Evidence from the Korean Health Panel. Journal of Korean Medical Science 2016; 31:336-44.

[39]Muir, T. Measuring social protection for long-term care. OECD Health Working Papers 2017:93.

[40]Official Bulletin State. Promotion of Personal Autonomy and Assistance for Persons in a Situation of Dependency Act (Act 39/2006 of 14th December). 2006.

[41]Montserrat Codorniu J. La sostenibilidad del Sistema para la Autonomía y Atención a la Dependencia (SAAD): presente y futuro. 2010.

[42]del Pozo Rubio R, Escribano Sotos F. Economic impact of informal care after the establishment of the law of dependence in Spain. Revista Espanola de Salud Publica 2012; 86:381-92.

[43]del Pozo-Rubio R, Pardo-Garcia I, Escribano-Sotos F. The co-payment of the dependence from the structural reform of 2012 in Spain. Gaceta Sanitaria 2017; 31:23-9.

[44]Montserrat Codorniú J, Montejo Sarriás I. Análisis de las medidas introducidas en la Resolución de 13/7/2012. Actas de la Dependencia Fundación Caser 2012; 6.

[45]Official Bulletin State. Resolución de 13 de julio de 2012, de la Secretaría de Estado de Servicios Sociales e Igualdad, por la que se publica el Acuerdo del Consejo Territorial del Sistema para la Autonomía y Atención a la Dependencia para la mejora del sistema para la autonomía y atención a la dependencia. 2012.

[46]Official Bulletin State. Real Decreto-ley 20/2012, de 13 de julio, de medidas para garantizar la estabilidad presupuestaria y de fomento de la competitividad. Boletín Oficial del Estado 2012; 14:50428-518.

[47]National Statistics Institute of Spain. Spanish Disability and Dependency Survey 2008. 2008.

[48]Official Bulletin State. Real Decreto 174/2011, de 11 de febrero, por el que se aprueba el baremo de valoración de la situación de dependencia establecido por la Ley 39/2006, de 14 de diciembre, de Promoción de la Autonomía Personal y Atención a las personas en situación de dependencia. BOE, 2011.

[49]Sosvilla-Rivero S, Moral-Arce I. Estimación de los beneficiarios de prestaciones de dependencia en España y del gasto asociado a su atención para 2007-2045. Gaceta Sanitaria 2011; 25:66-77.

[50]Oliva J, Vilaplana C, Osuna R. El valor social de los cuidados informales provistos a personas mayores en situación de dependencia en España. Gaceta Sanitaria 2011; 25:10814.

[51]Official Bulletin State. Real Decreto 1051/2013, de 27 de diciembre, por el que se regulan las prestaciones del Sistema para la Autonomía y Atención a la Dependencia, establecidas en la Ley 39/2006, de 14 de diciembre, de Promoción de la Autonomía Personal y Atención a las personas en situación de dependencia. 2013.

[52]Posnet J, lan S. Indirect cost in economic evaluation: the opportunity cost of unpaid inputs. Health Economics 1996; 5:13-23. 
[53]Van den Berg B, Brouwer WB, Koopmanschap MA. Economic valuation of informal care. The European Journal of Health Economics, formerly: HEPAC 2004; 5:36-45.

[54]Van den Berg B, Ferrer-i-Carbonell A. Monetary valuation of informal care: the well-being valuation method. Health Economics 2007; 16:1227-44.

[55]Vilaplana Prieto C. Estimación de la dependencia en España a partir de la EDAD 2008. Hacienda Publica Española 2010; 194:125-75.

[56]Wübker A, Sandra M, Zwakhalen G, Challis D, Suhonen R, Karlsson S, Zabalegui A, Soto M, Saks K, Sauerland D. Costs of care for people with dementia just before and after nursing home placement: primary data from eight European countries. The European Journal of Health Economics: HEPAC 2015; 16:689.

[57]Peña-Longobardo LM, Oliva-Moreno J. Economic valuation and determinants of informal care to people with Alzheimer's disease. The European Journal of Health Economics 2015; 16:507-15.

[58]Ortega-Ortega M, Montero-Granados R, de Dios Jiménez-Aguilera J. Differences in the economic valuation and determining factors of informal care over time: the case of blood cancer. Gaceta Sanitaria 2018; 32:411-7.

[59] Official Bulletin State. Real Decreto 1620/2011, de 14 de noviembre, por el que se regula la relación laboral de carácter especial del servicio del hogar familiar. 2011.

[60]Giorgi L, Verma V. European Social Statistics: Income, Poverty and Social Exclusion: 2nd Report. Office for Official Publications of the European Communities, Luxembourg 2002.

[61]Ayala L, Martínez R, Ruíz-Huerta J. Estrategias selectivas en las prestaciones sociales: efectos sobre la pobreza. Hacienda Publica Española 2003:157-84.

[62]National Statistics Institute of Spain. Life Conditions Survey. 2012.

[63]Casado D. Políticas públicas alternativas en el ámbito de la dependencia: un ejercicio de simulación para el caso español. Hacienda Publica Española 2008; 186:61-90.

[64]Stiglitz JE. Economics of the public sector. WW Norton \& Company Ltd., 2000.

[65]World Health Organization. Designing health financing systems to reduce catastrophic health expenditure. 2005.

[66]National Statistics Institute of Spain. Consumer Price Index 2012.

[67]Raghunathan TE, Lepkowski JM, Van Hoewyk J, Solenberger P. A multivariate technique for multiply imputing missing values using a sequence of regression models. Survey methodology $2001 ; 27: 85-96$.

[68]Economic and Social Council of Spain. Memoria sobre la situación socioeconómica y laboral de España 2014. 2015.

[69]Ortega E, Peñalosa J. Some thoughts on the Spanish economy after five years of crisis. Ocasional Documents Bank of Spain 2014; 1304.

[70]Economic and Social Council of Spain. Memoria sobre la situación socioeconómica y laboral de España 2012. 2013.

[71]Blomqvist A, Busby C. Long-term care for the elderly: Challenges and policy options. 2012. 
[72]Abellán García A, Esparza Catalán C, Pérez Díaz J. Evolution and structure of dependent people. Cuadernos de Relaciones laborales 2011; 29:43.

[73]Resolution of 2 December 2008, of the State Secretariat for Social Policy, Families and Dependency and Disability, on the Agreement the Territorial Council for Autonomy and Attention to Dependency, on determining the economic capacity of beneficiaries and the criteria of participation for beneficiaries in the services and benefits provided by the Dependency System. 